\title{
The effect of the addition of ground olive stones on the physical and mechanical properties of clay bricks
}

\author{
S. Arezki, N. Chelouah $\varangle$, A. Tahakourt \\ Laboratoire de Génie de Construction et d'Architecture, Faculté de Technologie, Université de Bejaia (Algérie) \\ $\triangle$ nasser_chelouah@yahoo.fr
}

\begin{abstract}
This study deals with the effect of ground olive stones (GOS) on the performance of fired clay bricks. Seven different clay-GOS mixes with $0,1,2,3,4,5$ and $10 \mathrm{wt} \%$ of GOS respectively were used for making fired brick samples. All samples were fired at $900{ }^{\circ} \mathrm{C}$. The technological properties of the resultant material were then determined, including shrinkage, apparent density, pore size distribution, thermal conductivity, water absorption, and compressive and flexural strength. The addition of GOS to the mixture reduced the compressive strength of fired clay bricks. All clay brick pieces exhibited low firing shrinkage. It was apparent that as the percentage of GOS increased in the body, there was a noticeable increase in porosity. The water absorption coefficient decreased with increasing additions. The results indicated that thermal conductivity decreases with decrease in density and increase in porosity in fired clay bricks.
\end{abstract}

KEYWORDS: Brick; Organic material; Temperature; Compressive strength; Thermal Analysis

Citation/Citar como: Arezki, S.; Chelouah, N.; Tahakourt, A. (2016) The effect of the addition of ground olive stones on the physical and mechanical properties of clay bricks. Mater. Construcc. 66 [322], e082. http://dx.doi.org/10.3989/ mc.2016.00815.

RESUMEN: Efecto de la adición de huesos de aceituna triturados en las propiedades físicas y mecánicas de ladrillos de arcilla. En este trabajo se ha estudiado el efecto de la incorporación de huesos de aceituna triturados en las prestaciones de ladrillos de arcilla cocida. Se utilizaron siete proporciones de huesos de aceituna $0 \%, 1 \%$, $2 \%, 3 \%, 4 \%, 5 \%$ y $10 \%$ en peso. Todas las muestras se calcinaron a $900{ }^{\circ} \mathrm{C}$ y posteriormente se determinaron las propiedades resultantes, incluyendo la densidad aparente, retracción, distribución de tamaños de poro, conductividad térmica, absorción de agua y resistencias mecánicas. La adición de huesos de aceituna molidos a la mezcla redujo la resistencia a la compresión de los ladrillos de arcilla cocida. Además se observó que todas las piezas de ladrillo mostraron baja retracción tras exposición a altas temperaturas. Como era de esperar a medida que el porcentaje de huesos de aceituna molidos aumentó, la porosidad se incrementó de manera evidente. El coeficiente de absorción de agua disminuyó con el aumento del porcentaje de sustitución. Los resultados indicaron que la conductividad térmica disminuye con la disminución de la densidad y el aumento de la porosidad.

PALABRAS CLAVE: Ladrillo; Material orgánico; Temperatura; Resistencia a la Compresión; Análisis térmico

Copyright: (C) 2016 CSIC. This is an open-access article distributed under the terms of the Creative Commons Attribution-Non Commercial (by-nc) Spain 3.0 License. 


\section{INTRODUCTION}

Both waste recycling and energy saving are currently important fields of research. Using recycled waste to improve brick performance could be a solution to both these problems. The aim is to create bricks which are lighter than traditional bricks and, in particular, have better insulation ability. The recycling of waste as a sustainable construction material appears to be not only a viable solution to pollution problems, but also an economical option in the design of green buildings (1).

Many attempts have been made to incorporate waste into the production of bricks, including sawdust, coal, paper sludge and straw (2), spent grains (3), paper mill residue and rice husk ash (4), sludge waste from the natural rubber manufacturing process (5), rubber (6), tannery sludge (7), recycled paper processing residues (8), waste tea (9), sawdust, tobacco and grass (10), cherry seeds (11), cigarette butts (12), bagasse waste (13), sugarcane bagasse (14), fly ash (15), quarry waste and slag (16) and granite powder (17), among others. Most of these kinds of recycled waste demonstrated both advantages and drawbacks.

The use of olive stones in the building industry has been studied by many research groups. Barreca and Fichera (18) used olive stones as addition in cement lime mortar in order to improve its insulation and reduce its density: alperujo has high organic material content. Since then, many researchers have studied the recovery of alperujo in fired brick manufacturing. The physical and mechanical properties of these bricks have been compared to those with no added alperujo in order to evaluate whether this method is suitable for industrial implementation (19-20). Recently, other research groups have incorporated olive mill wastewater as a substitute for water in brick manufacturing whose physical stability was confirmed (21-23). De la Casa and Castro (24) used washed olive pomace ashes to replace clay in brick manufacture.

The different methods described above produce bricks from waste materials, either by using high temperature kiln firing, or by relying on cementing (as in ordinary Portland cement concrete). Thus, they still have the drawbacks of high-energy consumption and large quantities of greenhouse gas emissions.

Researchers have therefore studied the production of bricks from waste materials based on geopolymerization. Geopolymerization is a technology that relies on the chemical reaction of amorphous silica and alumina-rich solids with a high-alkaline solution at ambient or slightly raised temperatures in order to transform amorphous silica into semicrystalline aluminosilicate inorganic polymer or geopolymer (25).

However, Neves Monteiro and Vieira (26) concluded that the production of clay construction materials (bricks, tiles, blocks) by firing is, and probably will be for the next two decades, more advantageous than cementing or geopolymerization. The incorporation of fuel-containing waste, in association with a relatively low firing temperature of $600{ }^{\circ} \mathrm{C}$, can help reduce the energy needed to produce a clay brick to much less than the average of $2 \mathrm{kWh}$ indicated by Zhang (25).

Santos et al. suggest (27) that the widespread use of vegetable fibers as a source of raw material may, in the near future, enable us to engineer composites and new materials for multipurpose applications, using new concepts and technologies.

The judicious use of ground olive stones (GOS) in clay bricks is desirable not only for its technical benefits, but also from an ecological perspective. Olive stones are abundant in Algeria, and they are discharged into rivers and coastal waters. This causes pollution, which can have negative effects on human health and the wider environment-effects that would be lessened if the superfluous GOS could be diverted towards a practical purpose. The aim of this paper, then, is to study the effect of the addition of ground olive stones on the physical and mechanical properties of fired clay bricks.

\section{EXPERIMENTAL METHODS}

Mineralogical composition was determined by X-ray Diffraction (XRD). The test was carried out on a Siemens D5000 instrument. An X-Ray fluorescence spectrometer machine, Rigaku RIX 3000, was used to determine the chemical composition of the major components of clay. Particle size distribution of clay material and GOS was carried out with a Coulter LS 230 apparatus. Differential thermal analysis (DTA) and differential thermal gravimetric (DTG) were employed for measuring the thermal stability and phase transformation of raw materials (GOS and clay) at a heating rate of $15^{\circ} \mathrm{C} / \mathrm{min}$, with the temperature ranging from $30^{\circ} \mathrm{C}$ to $1000^{\circ} \mathrm{C}$ under air atmosphere. The test was carried out on a Netzsch instrument STA 409 PC Luxx. The analysis of fatty substances in the olive stones was carried out with a Soxhlet machine, which is a device for extracting components from a solid. The pore size distribution (in the $0.01-1000 \mu \mathrm{m}$ range) was determined by mercury intrusion porosimetry (Thermo Finnigan Pascal 140/240) with an experimental uncertainty of about $1 \%$ relative. The system's porosity was assessed via scanning electron microscopy (SEM) with a Hitachi S 4100. Underwater (hydrostatic) weighing, based on Archimedes' Principle, was used to determine the apparent density and the porosity. The Hot Disk method was used to measure thermal conductivity. The linear shrinkage after drying and firing was determined using calipers with a precision of $\pm 0.01 \mathrm{~mm}$. Compressive and flexural strength was determined in a Controls 65-L11D laboratory 
testing machine by applying the load centered in the upper face of the brick at a speed of $20 \mathrm{MPa} / \mathrm{s}$ until fracture.

Water absorption was performed according to NA 1957 (28). One major surface of each test sample was placed in contact with liquid water. While the samples were stored in stainless steel containers during (the 10-minute test). On the container bottom, a $5 \mathrm{~mm}$ high spacer was arranged to support the sample and to guarantee a defined thickness of water layer between the test surface and the container. Water was maintained at $22 \pm 1{ }^{\circ} \mathrm{C}$. The mass $\mathrm{M}$ in grams of water absorbed by the brick from the beginning of immersion was then measured (Table 3).

The water absorption coefficient was determined as described in NA 1957 (28). The water absorption coefficient of brick can be expressed by the following equation [1]:

$$
\mathrm{C}=(\mathrm{M} \times 100) /\left(\mathrm{S} \times \mathrm{t}^{1 / 2}\right)
$$

Where $\mathrm{M}$ is the mass in grams of water absorbed by the brick from the beginning of immersion, $\mathrm{S}$ is the surface ( $4 \mathrm{~mm} \times 8 \mathrm{~mm}$ size) of the submerged face expressed in $\mathrm{cm}^{2}$ and $\mathrm{t}$ is the time in minutes elapsed from the start of immersion. Under the conditions of the test ( $t=10$ minutes).

\section{CHARACTERIZATION OF THE MATERIALS}

\subsection{Materials}

The clay used comes from the city of Bejaia in Algeria. The X-ray pattern of the clay (Figure 1) shows that the main crystalline phases are kaolinite, quartz and calcite.

The chemical and mineral composition of the clay used in this experiment are listed in Tables 1 and 2 respectively. The chemical data correlate with the mineral composition, and the silica and alumina contents agree with the quartz and kaolinite content. The organic matter of clay is present only in small amounts $(1.80 \mathrm{wt} \%)$.

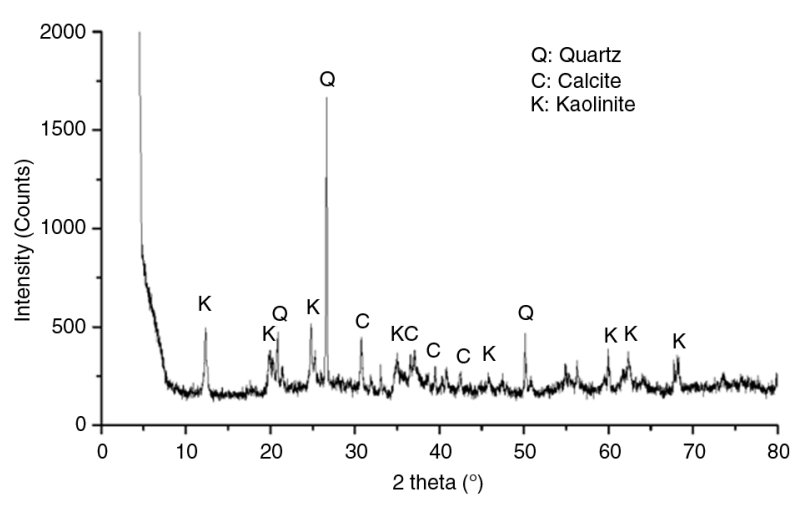

Figure 1. X-ray diffraction of the clay.
According to this analysis, the clay used in the experiments was typical carbonate clay. The loss on ignition at $1100{ }^{\circ} \mathrm{C}$ was $15.32 \mathrm{wt} \%$, which is within the adequate range for clay brick production. The dehydroxylation and carbonates decomposition (e.g. mineral carbonate and organic matter in clay) create porosity in the clay during the process (drying and firing).

This kind of clay consists of sandy grains $(15 \%)$, clay particles $(20 \%)$ and dusty grains $(65 \%)$. Its particle size distribution, measured using a laser diffraction technique, is given in Figure 2. The results show that the clay powder presented the largest fraction of grains between the 2 and $20 \mu \mathrm{m}$ sizes. This value of $65 \%$ indicates that the clay powder, in accordance with the grain size range, is adequate to obtain good green density during compaction and good reactivity during firing. This clay brick raw material has a low concentration of sand, and, consequently, a high plasticity.

In order to investigate the reactions taking place during the firing process, clay and GOS were studied by thermal analysis. The TGA curve of clay without addition showed a weight loss of $14.2 \%$ (Figure 3).

The DTA curve for the sample of clay without addition is shown in Figure 4. Three endothermic peaks are seen in the DTA curve. The first endothermic peak (at $55.71^{\circ} \mathrm{C}$ ) is attributable to the evolution of the physically-absorbed water by the kaolinite platelets in the clay. The second endothermic peak (at $549.67^{\circ} \mathrm{C}$ ) is also caused by water evolution, but is due to dehydroxylation of kaolinite leading to formation of metakaolinite. The third endothermic peak (at $740{ }^{\circ} \mathrm{C}$ ) is related to the calcareous decomposition into mainly $\mathrm{CaO}, \mathrm{CO}_{2}$ and chemical combination water. However, the calcareous used is rich in calcite $\left(\mathrm{CaCO}_{3}\right)$. Finally, in the interval between 600 and $900{ }^{\circ} \mathrm{C}$, a weight loss of $12.5 \%$ occurs, probably due to decomposition of $\mathrm{CaCO}_{3}$ (Figure 3).

The olive stones used were the waste by-product of a modern oil extraction machine. They were dried for a few days in the air to facilitate the separation of their shells. They were then ground and sieved to obtain particles with sizes below or equal to $500 \mu \mathrm{m}$ in diameter.

The particle size distribution of GOS is given in Figure 2, measured using a laser diffraction technique. The mix of GOS mainly consists of fractions with the grain size from $63 \mu \mathrm{m}$ to $500 \mu \mathrm{m}(70 \%)$. Grains larger than $500 \mu \mathrm{m}$ make up only $2 \%$, but dusty particles (smaller than $63 \mu \mathrm{m}$ ) make up $28 \%$.

The chemical analysis shows that olive stones are composed mainly of cellulose $(33.42 \%)$, lignin $(22.61 \%)$, hemicellulose $(15.12 \%)$, fats $(3.47 \%)$, and a small amount of ash $(2.41 \%)$. They have a very high organic matter content (mainly lignin, cellulose, hemicellulose, and fat).

The results of the thermal analysis for the GOS can be seen in Figures 4 and 5. We observe a small 
TABle 1. Chemical composition of clay (oxide wt $\%$ )

\begin{tabular}{lccccccccccc}
\hline $\mathbf{S i O}_{2}$ & $\mathbf{A l}_{2} \mathbf{O}_{3}$ & $\mathbf{F e}_{2} \mathbf{O}_{3}$ & $\mathbf{C a O}$ & $\mathbf{M g O}$ & $\mathbf{K}_{2} \mathbf{O}$ & $\mathbf{N a}_{2} \mathbf{O}$ & $\mathbf{S O}_{3}$ & $\mathbf{M n O}$ & $\mathbf{T i O}_{2}$ & $\mathbf{P}_{2} \mathbf{O}_{3}$ & $\mathbf{L O I}$ \\
\hline 46.60 & 10.80 & 5.15 & 14.70 & 1.89 & 1.57 & 0.89 & 0.50 & 0.24 & 1.15 & 0.19 & 15.32 \\
\hline
\end{tabular}

TABle 2. Mineral composition of clay ( $\left.w t^{\%} \%\right)$

\begin{tabular}{lcccc}
\hline Quartz & Kaolinite & Calcite & Organic matter & Accessories \\
\hline 53.17 & 25.35 & 12.98 & 1.80 & 4.70 \\
\hline
\end{tabular}

endothermic peak at $55.71{ }^{\circ} \mathrm{C}$, which can be attributed to moisture loss $(0.5 \%)$. As the temperature increases, weight loss increases. At $100{ }^{\circ} \mathrm{C}$, the GOS continues to lose weight $(5 \%)$. The exothermic peak, which occurs at $100{ }^{\circ} \mathrm{C}$, is probably attributable to the elimination of fats. We observe another exothermic peak at $250{ }^{\circ} \mathrm{C}$, smaller than the first due to the degradation of hemicelluloses and decomposition of cellulose. The weight loss is $48.88 \%$. The last exothermic peak, at $340^{\circ} \mathrm{C}$, may be due to the decomposition of lignin. The weight loss is $15 \%$. Finally, in the interval from 55.71 to $340^{\circ} \mathrm{C}$, the TGA curve shows a total weight loss of $69.38 \%$, indicating that

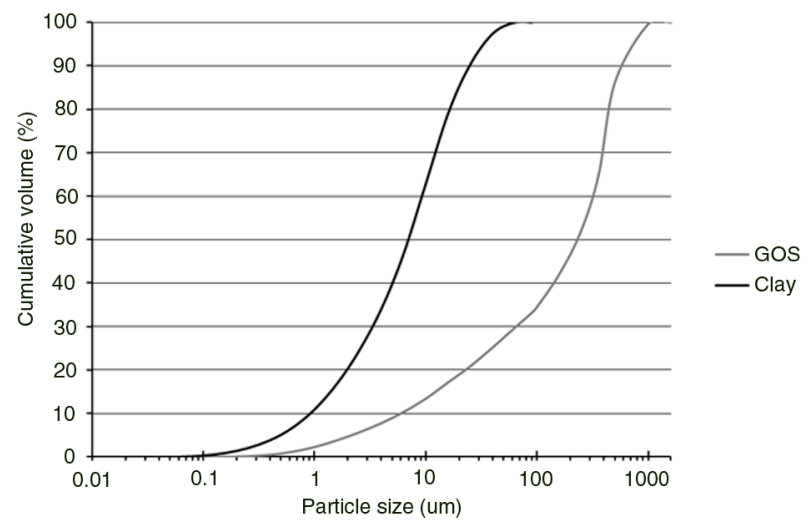

Figure 2. Cumulative curves of the clay and GOS.

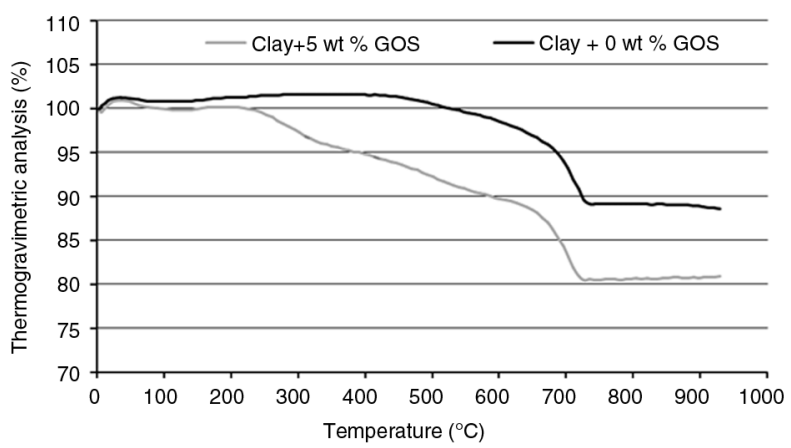

FIgURE 3. TGA of the samples containing $5 \mathrm{wt} \%$ of GOS compared with the control sample. ash is produced in the combustion. The porosity in the clay brick samples was caused when the GOS were burning out totally at $650{ }^{\circ} \mathrm{C}$ during the firing process.

DTA curves for the samples of clay without addition and clay with $5 \mathrm{wt} \%$ GOS are shown in Figure 4. At $55.71{ }^{\circ} \mathrm{C}$, we observe two endothermic peaks. The difference in the DTA curves can be attributed to moisture loss of GOS $(0.5 \%)$. At a temperature of $740{ }^{\circ} \mathrm{C}$, a weight loss occurs, probably due to the chemical combination water in the clay, which is part of the molecular structure and is only affected by temperatures above $400{ }^{\circ} \mathrm{C}$. The exothermic peak between $190{ }^{\circ} \mathrm{C}$ and $340{ }^{\circ} \mathrm{C}$ of the sample with $5 \mathrm{wt} \%$ of GOS corresponds to the loss of organic matter (fats, hemicellulose, cellulose, and lignin). This is verified by the TGA of GOS, which shows a

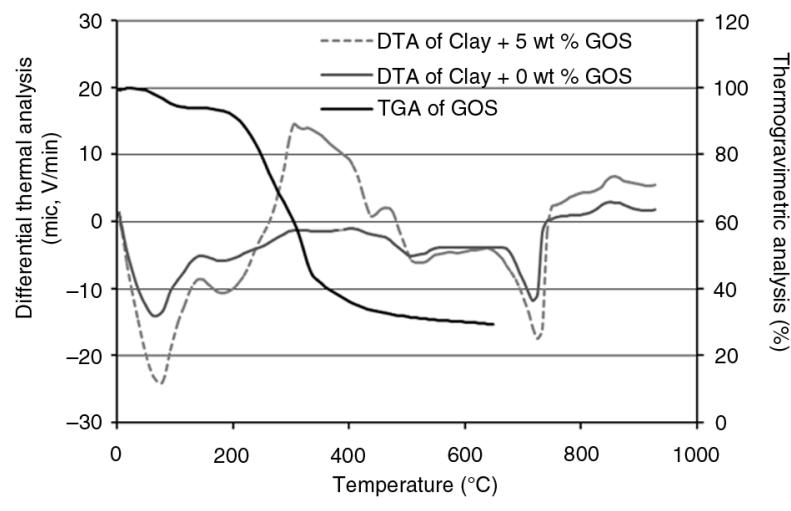

FIgURE 4. Comparison between differential thermal analysis (DTA) of clay containing $5 \mathrm{wt} \%$ of GOS with the control sample ( $0 \mathrm{wt} \%$ addition).

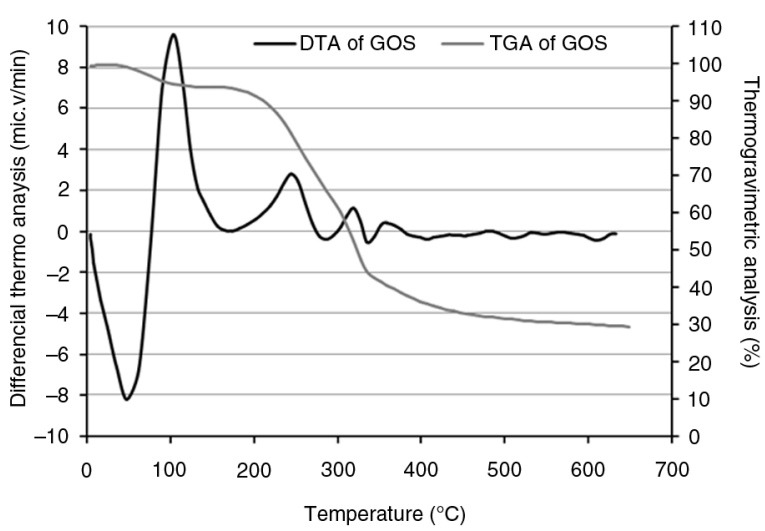

Figure 5. TGA and DTA of GOS 


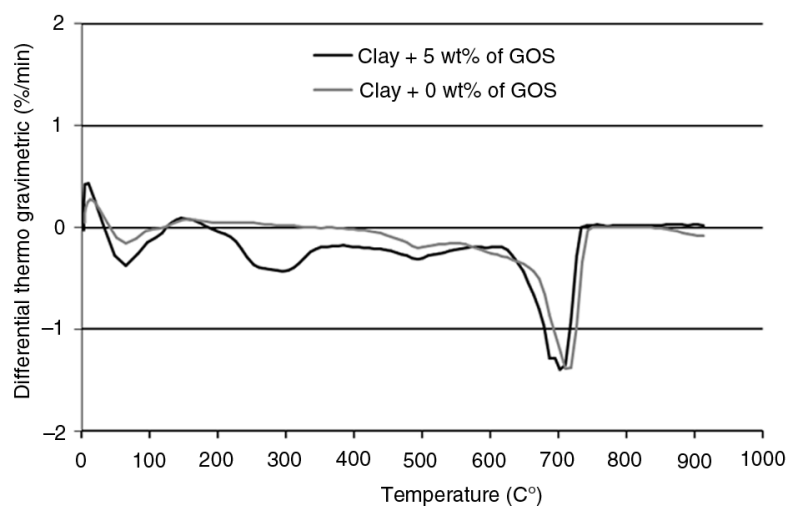

FIGURE 6. Speed reduced mass of the samples containing $5 \mathrm{wt} \%$ of GOS by DTG compared with the control sample.

similar loss in mass at the same temperature interval (Figures 4 and 5). The sample with $5 \mathrm{wt} \%$ of GOS has a total weight loss higher $(19 \%)$ than the sample of clay without addition (14.20\%). This change corresponds to the combustion of organic matter of GOS. The clay with $5 \mathrm{wt} \%$ of GOS emits more heat than the clay without. This shows that adding GOS can help to increase the temperature in the furnace using the heat given off. The TGA analysis curve of GOS is typical of a solid fuel (Figures 4 and 5).

Figure 6 shows the differential thermal gravimetric (DTG) curves for samples with $5 \mathrm{wt} \%$ additions of GOS compared with the control sample (clay without addition). A comparison of the DTG speedreduced mass of the samples containing $5 \mathrm{wt} \%$ of GOS with that of the control sample confirmed the results of the thermal analysis of GOS. At interval temperatures between $55.7^{\circ} \mathrm{C}$ and $340{ }^{\circ} \mathrm{C}$, we can clearly observe that the speed-reduced mass of the sample with $5 \mathrm{wt} \%$ of GOS is higher than that of the sample of clay without addition (control sample). At $740^{\circ} \mathrm{C}$, the speed-reduced mass of the sample with $5 \mathrm{wt} \%$ of GOS and the sample without addition are identical, which could be explained by the elimination of structural water and calcareous decomposition by combustion in the clay. The GOS burned out totally - at $650{ }^{\circ} \mathrm{C}$ - during the firing process.

\section{PREPARATION OF THE BRICK SAMPLES}

In this study, seven different clay-GOS mixes with $0 \%, 1 \%, 2 \%, 3 \%, 4 \%, 5 \%$ and $10 \%$ by weight of GOS were used for making fired brick samples. According to NF P 94-051 (29), the clay and the
GOS with different wt $\%(0,1,23,4,5$, and 10$)$ were mixed, and then water was added and mixed until the plastic limit of the mixture was reached (Atterberg method). The plastic limit is the water content, in wt $\%$, at which clay with different additions of GOS can no longer be deformed by rolling into $3.2 \mathrm{~mm}$ diameter threads without crumbling. For each series, the water content in wt $\%$ was determined. The results are given in Table 3. The water content of the mixture gradually increases with the addition of GOS. The use of GOS in dry conditions reduces the clay formulation's plasticity. The results in (23) demonstrate that mixing waste water from olive oil extraction instead of fresh water in the extrusion of ceramic bricks has an additional lubricating effect. Similar results have previously been found in the extrusion effect when adding olive mill wastewater $(21,22)$.

Seven series of samples (10 samples in each series) were prepared for testing according to their percentage of added GOS. Series 1 was the standard clay brick $(0 \mathrm{wt} \%$ addition) as a control sample. Series 2 , $3,4,5,6,7$ contained additions of $1,2,3,4,5$ and $10 \mathrm{wt} \%$ respectively. A hydraulic press with a uniaxial load was then used to press the mixture into a mould (40 $\mathrm{mm} \times 40 \mathrm{~mm} \times 80 \mathrm{~mm}$ size). The samples formed were air-dried in the laboratory for 72 hours, then dried again in an oven at $105^{\circ} \mathrm{C}$ until there was no weight loss. The green brick samples were fired using the following cycle: up to $600^{\circ} \mathrm{C}$ with a heating rate $2{ }^{\circ} \mathrm{C} / \mathrm{min}$ (a slow rate of temperature increase at the beginning in order to assure the incineration of organic substances without inflammation), then $5^{\circ} \mathrm{C} / \mathrm{min}$ until $900^{\circ} \mathrm{C}$. The samples were then cooled to room temperature in the furnace.

\section{TEST RESULTS AND DISCUSSION}

The following technological properties of the clay bricks have been determined in accordance with standard procedures: dry shrinkage, weight loss on drying, total shrinkage after firing, loss mass after firing, water absorption, porosity, thermal conductivity, and flexural and compressive strength. The statistical parameters, the mean, and the standard deviation were calculated for each property at each $\mathrm{wt} \%$ of GOS. The technological properties are summarized in Table 4.

It can be observed that dry shrinkage, shrinkage after firing and mass loss after firing increased with increasing percentage of GOS. However, water absorption and apparent density decreased as GOS were added in the brick composition.

TABLE 3. Water content of samples (wt $\%)$

\begin{tabular}{lccccccc}
\hline & $\mathbf{0} \mathbf{w t} \%$ & $\mathbf{1} \mathbf{w t} \%$ & $\mathbf{2} \mathbf{w t} \%$ & $\mathbf{3} \mathbf{w t} \%$ & $\mathbf{4} \mathbf{w t} \%$ & $\mathbf{5} \mathbf{w t} \%$ & $\mathbf{1 0} \mathbf{w t} \%$ \\
\hline Water content $\mathbf{~ w t} \%)$ & 20.76 & 20.90 & 21.73 & 22.12 & 22.75 & 23.01 & 25.13 \\
\hline
\end{tabular}


TABLE 4. Mean and standard deviation of physical and mechanical properties of fired clay bricks

\begin{tabular}{lccccccc}
\hline & \multicolumn{7}{c}{ Mean Standard deviation } \\
\cline { 2 - 8 } & $\mathbf{0} \%$ & $\mathbf{1 \%}$ & $\mathbf{2} \%$ & $\mathbf{3} \%$ & $\mathbf{4} \%$ & $\mathbf{5 \%}$ & $\mathbf{1 0} \%$ \\
\hline Dry shrinkage (\%) & 1.38 & 1.56 & 1.69 & 1.81 & 1.06 & 2.38 & 2.40 \\
& 0.019 & 0.016 & 0.022 & 0.026 & 0.030 & 0.025 & 0.018 \\
Total shrinkage after firing (\%) & 1.63 & 1.69 & 1.75 & 1.94 & 1.19 & 2.68 & 2.85 \\
& 0.014 & 0.021 & 0.029 & 0.026 & 0.019 & 0.020 & 0.017 \\
Apparent density (g/cm ${ }^{3}$ ) & 1.69 & 1.58 & 1.54 & 1.49 & 1.46 & 1.42 & 1.32 \\
& 0.023 & 0.033 & 0.027 & 0.032 & 0.031 & 0.035 & 0.030 \\
Total mass loss after firing (\%) & 14.33 & 15.01 & 15.69 & 16.37 & 17.03 & 17.67 & 20.61 \\
& 0.032 & 0.039 & 0.035 & 0.038 & 0.040 & 0.033 & 0.035 \\
Water absorption (\%) & 28.34 & 27.59 & 26.21 & 25.84 & 24.74 & 24.00 & 18.53 \\
& 0.189 & 0.212 & 0.193 & 0.203 & 0.223 & 0.192 & 0.198 \\
Compressive strength of no fired samples (MPa) & 4.88 & 4.97 & 5.32 & 5.75 & 5.98 & 6.15 & 6.88 \\
& 1.38 & 1.56 & 1.69 & 1.81 & 1.06 & 2.38 & 2.40 \\
Compressive strength of fired samples (MPa) & 24.06 & 22.68 & 22.14 & 21.69 & 21.27 & 20.46 & 15.11 \\
& 1.63 & 1.69 & 1.75 & 1.94 & 1.19 & 2.68 & 2.85 \\
Flexural strength of no fired samples (MPa) & 8.62 & 7.86 & 7.15 & 6.63 & 6.18 & 5.59 & 3.83 \\
& 1.69 & 1.58 & 1.54 & 1.49 & 1.46 & 1.42 & 1.32 \\
\hline
\end{tabular}

In drying stage, the clay bricks showed low linear shrinkage. Before firing, it is necessary to obtain a low value of linear shrinkage in order to avoid cracks, fissure, and warpage. The linear shrinkage shows a small increase owing to water content, which increased in proportion to additions (Tables 3 and 4).

As the results show, all clay brick pieces exhibited low firing linear shrinkage, varying from 1.63 to $2.85 \%$ (Table 4)-within the safety limits for industrial production of clay bricks. Fired clay bricks must have a firing linear shrinkage lower than $8 \%$ in order to retain good mechanical performance (30) as a large contraction may cause tension and breakage (21), creating structural problems. In Table 4, firing linear shrinkage clearly depends on the GOS wt $\%$ used. In samples with the addition of GOS, contraction occurs, which could be related to the increase of furnace temperature caused by the combustion of GOS.

The total mass loss after firing the samples studied varies between 14 and $21 \%$ (Table 4 ). When brick samples are fired, the organic matter contained in GOS is driven off. Indeed, the addition of GOS into the clay mixture creates porosity in the system during the process (drying and firing) via dehydroxylation and carbonate decomposition (e.g. mineral carbonates from clay and organic ones from GOS). The results indicate that the incorporation of 5 and $10 \mathrm{wt} \%$ of GOS is beneficial for manufacturing good-quality bricks, obtaining an apparent density of 1.42 and $1.32 \mathrm{~g} / \mathrm{cm}^{3}$ respectively (Table 4 ). In (19), the value obtained with $10 \mathrm{wt} \%$ of wet pomace was $1.42 \mathrm{~g} / \mathrm{cm}^{3}$. The difference in mass loss after firing can be attributed to the use of GOS in dry conditions, which requires more water to mould the mixture.
Figures 4 and 5 illustrate the weight loss between $100{ }^{\circ} \mathrm{C}$ and $340{ }^{\circ} \mathrm{C}$ of the GOS. The formation of voids leads to a decrease in mass. Increasing the percentage of GOS has caused a reduction in apparent density (Table 4).

The main reason for this is the combustion of the added GOS. Thus, in order to retain good performance, mass loss should remain below 15\% (30). As for linear shrinkage, it is not possible to compare the mass loss of different additives in clay bricks. Depending on their characteristics (chemical composition, density), the results are completely different.

To ensure the engineering quality of a material, especially for building construction use, mechanical testing is the essential criterion. In this study, the compressive strength of non-fired clay bricks (in their raw state) increased proportionally to the percentage of GOS (Figure 7). The cellulose materials contained in olive stones are fibrous and act as a structural binding agent before the brick is fired. Santos et al. reported that the purpose of the fibre reinforcement is to improve mechanical properties (27). This increase is useful to reduce falls due to displacement of bricks.

On the contrary, the results obtained with fired clay bricks indicate that the addition of GOS decreases the compressive strength. For the manufactured bricks with $10 \mathrm{wt} \%$ of GOS, compressive strength is $15.11 \mathrm{MPa}$. As a result in (19), manufactured bricks with $10 \mathrm{wt} \%$ of wet pomace showed the maximum compressive strength value of 40.22 MPa due either to the type of porosity created (closed porosity) or, more likely, to the pore shape (spherical) (31). Higher porosity and pore characteristics have important consequences concerning 


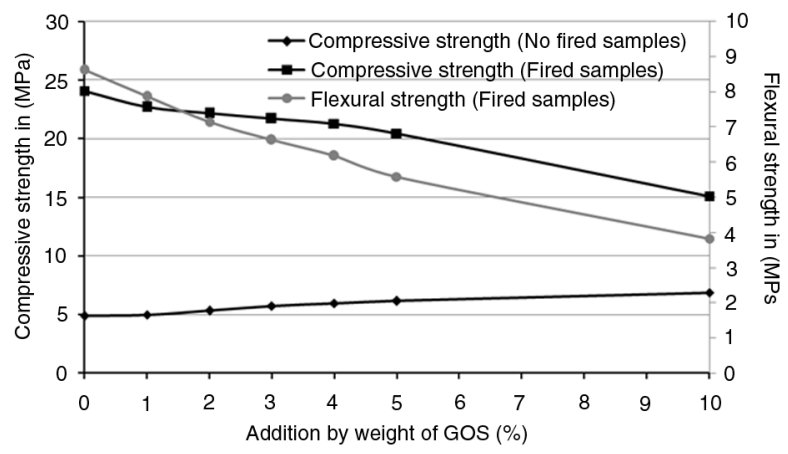

FIgURE 7. Compressive and flexural strength of samples according to $\mathrm{wt} \%$ of GOS.

the product's mechanical resistance (19). That the increased addition of GOS led to a decrease in compressive strength is probably due to the formation of closed, non-spherical pores. However, the values are still higher than that required by Algerian standards, which require a brick's compressive strength to measure between 10 and $40 \mathrm{MPa}$ for use in construction (NA 5023) (32). According to industrial standards, for a traditional brick to be sufficiently strong, it must not have a compressive strength below $10 \mathrm{MPa}$ (30). The samples shown in Table 4 are all above this recommended limit.

It was also observed that the clay bricks presented flexural strength between 3.83 and $8.62 \mathrm{MPa}$, which is acceptable for industrial production of clay bricks (Figure 7). Increasing wt $\%$ GOS does not improve compressive and flexural strength. These mechanical properties are related to the closed pores formed during firing.

Water absorption is an indirect indicator for open porosity, and is an important factor affecting the durability of clay bricks. In this study, the water absorption coefficient of clay bricks was in the range of $18-27 \%$. According to NA 1957 (28),

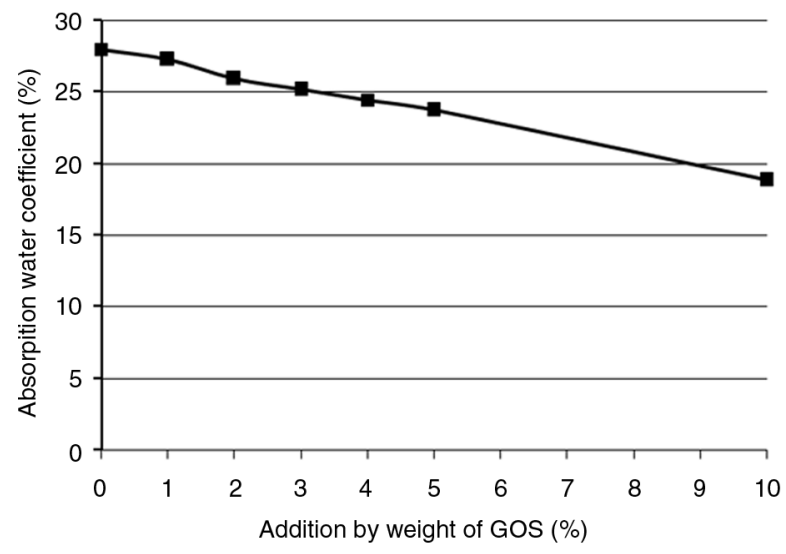

FIGURE 8. Absorption coefficient water according to $\mathrm{wt} \%$ of GOS the optimum value of water absorption coefficient is considered to be less than $30 \%$.

The water absorption coefficient (Figure 8) and water absorption measurement (Table 4) decreased with increasing additions. The GOS additions in the sample were burnt out through the process of firing, leaving abundant closed pores in the clay bricks. Water absorption is related to the volume of the open pores due to the decomposition of carbonates contained in clay. The oils present in GOS can increase the firing temperature in the furnace. This increased firing temperature enhanced the bricks' thermal driving force and promoted densification (23). As the firing temperature increased, the increased surface tension of the liquid phase resulted in capillary pressure, which tends to approach the particle. In this process, partial open porosity was transformed into a closed porosity (23). However, water absorption is not related to the closed pores formed by the calcination of GOS. This accounts for the improved lower water absorption (Table 4). The measured water absorption indicated that the changes in the results were due to the type of porosity formed by the quantity and the type of waste used (33).

The pore structure of the brick made from pure clay (control sample) consists mainly of pores with the size of 0.06 to $1 \mu \mathrm{m}$ (Figure 9). These pores probably appear due to the dehydroxylation and carbonate decomposition present in the clay during the process (drying and firing). According to chemical analysis, loss on ignition reached up to $15.32 \%$ (Table 1). In terms of pores whose diameter ranged between 0.05 and $0.3 \mu \mathrm{m}$, the measured curve of the brick without additions shows slightly higher pore content than that of the brick with 5 wt $\%$ GOS. This difference corresponds to the combustion of organic matter of GOS, which increases the firing temperature and promotes the structural densification of clay brick.

As shown in Figure 9, the porous structure of the clay brick with $5 \mathrm{wt} \%$ GOS has been fully

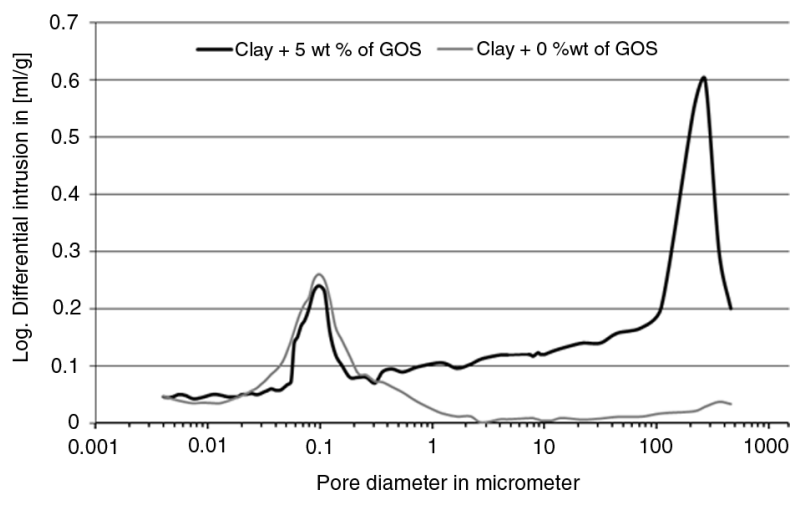

Figure 9. Comparison between pore size distribution of clay containing $5 \mathrm{wt} \%$ of GOS with the control sample $(0 \mathrm{wt} \%$ addition. 
developed. The firing process burns off the organic matter in the GOS, leaving behind closed pores. At wet pomace contents of 5 and $10 \%$, similar results were obtained by La Rubia-Garcia et al. (19).

The pores formed were between 100 and $500 \mu \mathrm{m}$ in size. The sizes of the GOS particles were below or equal to $500 \mu \mathrm{m}$ in diameter (Figure 2). The curve of Figure 9 shows a higher pore content, and that these pores have a diameter of $200 \mu \mathrm{m}$. As we have seen, the combustion of GOS during the firing process leads to an increase in firing temperature; this also occurs inside the brick's pores. Firing temperature is a key factor affecting shrinkage in the firing process (30). Shrinkage in bricks occurs as chemically and mechanically bound water is lost (34). A slight contraction inside a pore, caused by shrinkage, generates internal stresses and reduces the pore's diameter. The SEM image shows that the pores formed are closed but not spherical, and confirms the diameter values of pore size distribution (Figure 10).

Thermal conductivity is a decisive factor for the insulation capacity of a building material. The use of GOS as an addition in clay increased total porosity, and decreased apparent density, producing a decrease in thermal conductivity (Figure 11). The thermal conductivity of fired clay brick with 5 $\mathrm{wt} \%$ and $10 \mathrm{wt} \%$ of GOS decreased by about $20 \%$ and $57 \%$ respectively compared to fired clay brick without additions. This results from the increase in air volume obtained by the burning of the GOS, a process which leads to closed pores forming within the samples. These closed pores make the samples poor thermal conductors, and therefore good backup insulators.

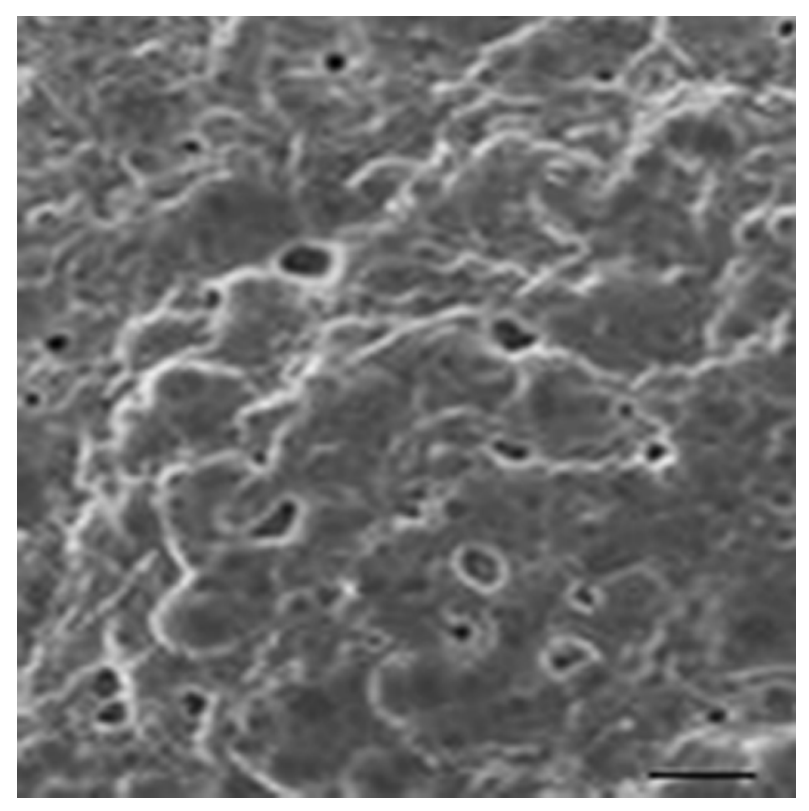

Figure 10. SEM micrographs of the clay with $5 \mathrm{wt} \%$ of GOS. Scale bar $500 \mu \mathrm{m}$.

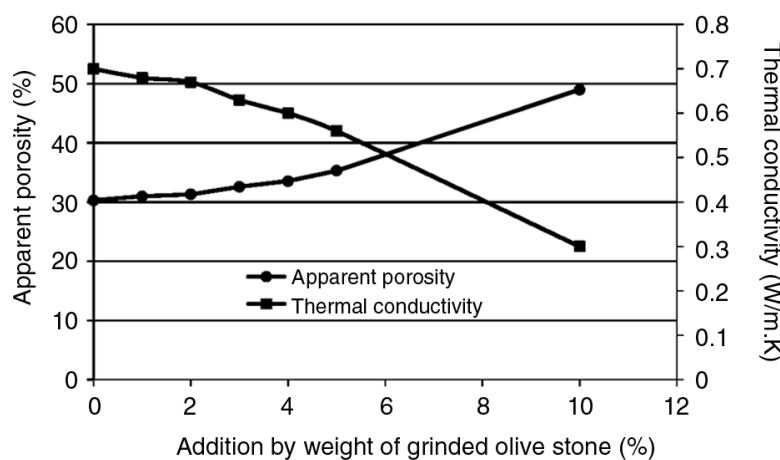

FIGURE 11. Relationship between thermal conductivity and apparent porosity according to the percentage of additions.

The thermal conductivity value with $10 \mathrm{wt} \%$ of wet pomace in (19) was $0.72 \mathrm{~W} / \mathrm{mK}$, which is higher than that found in the sample with $10 \mathrm{wt} \%$ of GOS. This difference is probably due to the closed pores formed during combustion of GOS, which have a smaller pore diameter. Small closed pores diameters promote a low thermal conductivity. Different behavior was observed by other authors, depending on the nature and quantity of pore-forming agents added to the mixture. The smallest decreases (around 7-10\%) have been recorded in samples utilizing bagasse from breweries, and urban sludge (BFB 2.5\% and SDG urban 15\% for Eliche-Quesada et al.) (32). However, thermal conductivity depends not only on the percentage of pores but also on their size and connectivity (8). In a similar way to previous work, the thermal conductivity decreases with increasing porosity (i.e. at higher density values). Thermal conductivity decreases drastically with up to $10 \%$ wet pomace content. Above $10 \%$ wet pomace, conductivity shows similar values for samples with $15 \%, 20 \%$ and $25 \%$ pomace, probably owing to greater pore size and/or greater connectivity of the pore system (19).

\section{CONCLUSIONS}

This study investigated the properties of manufactured bricks produced with clay and GOS. The following conclusions can be drawn from the experimental study. The results obtained indicate that the incorporation of GOS reduces the water absorption and the thermal conductivity of fired clay bricks. However, this decrease in water absorption may have positive effects when these fired clay bricks are used. This characteristic is an advantage because bricks without GOS additions absorb much of the water contained in mortar, causing it to crumble and creating a poor bond. GOS can act as an organic closed-pore forming agent in clay bricks, increasing their porosity, and so improving the thermal conductivity. GOS contain oil, and are easily combusted during the firing process; this combustion increases 
the temperature inside the formed pores and in the furnace. Although the addition of GOS decreases the mechanical properties of the bricks compared to pure clay ones, all the sample series tested nevertheless showed compressive strength values above the minimum requirements of existing regulations.

All of these findings show that GOS-addition clay bricks offer excellent returns on the energy used in firing. Thus, GOS are recommended as one of the most cost-effective alternative additions that can be used in fired clay brick manufacturing.

\section{REFERENCES}

1. Raut, S.P.; Ralegaonkar, R.V; Mandavgane, S.A. (2011) Development of sustainable construction material using industrial and agricultural solid waste: A review of wastecreate bricks. Construct. Build. Mat. 25 [10], 4037-4042. http://dx.doi.org/10.1016/j.conbuildmat.2011.04.038.

2. Demir, I.; Baspinar, M.S.; Orhan, M. (2005) Utilization of kraft pulp production residues in clay brick production. Build. Envir. 40 [11], 1533-1537. http://dx.doi.org/10.1016/j. buildenv.2004.11.021.

3. Russ, W.; Mortel, H.; Pittroff, R.M. (2005) Application of spent grains to increase porosity in bricks. Construct. Build. Mat. 19 [2], 117-126. http://dx.doi.org/10.1016/j.conbuildmat. 2004.05 .014

4. Raut, S.P.; Ralegaonkar, R.V.; Mandavgane, S.A. (2013) Utilization of recycle paper mill residue and rice husk ash in production of light weight bricks. Archives of civil and mechanical engineering 13 [2], 269-275. http://dx.doi. org/10.1016/j.acme.2012.12.006.

5. Vichaphund, S.; Intiya, W.; Kongkaew, A.; Loykulnant, S.; Thavorniti, P. (2012) Utilization of sludge waste from natural rubber manufacturing process as a raw material for clayceramic production. Envir. Tech. 33 [22], 2507-2510. http:// dx.doi.org/10.1080/09593330.2012.668941.

6. Turgut, P.; Yesilata, B. (2008) Physico-mechanical and thermal performances of newly developed rubber-added bricks. Energy and Buildings 40, 679-688. http://dx.doi.org/10.1016/ j.enbuild.2007.05.002

7. Basegio, T.; Berutti, F.; Bernades, A.; Bergmann, C.P. (2002) Environmental and technical aspects of the utilization of tannery sludge as a raw material for clay products. J. Eur. Cer. Soc. 22, 2251-2259. http://dx.doi.org/10.1016/ S0955-2219(02)00024-9.

8. Sutcu, M.; Akkurt, S. (2009) The use of recycled paper processing residues in making porous brick with reduced thermal conductivity. Ceram. Int. 35, 2625-2631. http://dx.doi. org/10.1016/j.ceramint.2009.02.027.

9. Demir, I. (2006) An investigation on the production of construction brick with processed waste tea. Build. Envir. 41 [9], 1274-1278. http://dx.doi.org/10.1016/j.buildenv.2005. 05.004 .

10. Demir, I. (2008) Effect of organic residues addition on the technological properties of clay bricks. Waste Manag. 28 [3], 622-627. http://dx.doi.org/10.1016/j.wasman.2007. 03.019 .

11. Barbieri, L.; Andreola, F.; Lancellotti, I,; Taurino. R. (2013) Management of agricultural biomass wastes. Preliminary study on characterization and valorisation in clay matrix bricks. Waste. Manag. 33 [11], 2307-2315. http://dx.doi.org/ 10.1016/j.wasman.2013.03.014.

12. Abdul Kadir, A,; Abbas Mohajerani, A. (2011) Bricks: An excellent building material for recycling wastes - a review. Proceedings of the IASTED International Conference July 4-6, 2011 Calgary, AB, Canada. Environmental Management and Engineering (EME 2011). http://dx.doi. org/10.2316/P.2011.736-029.

13. Martinez -Cartas, M.L.; Eliche-Quesada, D.; Cruz-Pérez, N. Corpas-Iglesias, F.A. (2012) Utilization of bagasse from the beer industry in clay brick production for building.
Mater: Construcc. 62 [306], 199-212. http://dx.doi.org/10.3989/ mc.2012.63410.

14. Viruthagiri, G.; Sathiya, P.S.; Shanmugam, N. (2014) Reuse of Sugarcane Bagasse Ash (SCBA) for Clay Brick Production. Indian Journal of applied Research 4, 1-5. http://dx.doi.org/ 10.15373/2249555X/August2014/188.

15. Cultrone, G.; Sebastián E. (2009) Fly ash addition in clayey materials to improve the quality of solid bricks. Construct. Build. Mat. 23 [11], 78-84. http://dx.doi.org/10.1016/j. conbuildmat.2008.07.001

16. El-Mahllawy, M.S. (2008) Characteristics of acid resisting bricks made from quarry residues and waste steel slag. Construct. Build. Mat. 22, 1887-1896 http://dx.doi.org/ 10.1016/j.conbuildmat.2007.04.007.

17. Xavier, G.C.; Saboya, F.; Maia, P.C.; Alexandre, J. (2012) Durability of fired clay bricks containing granite powder. Mater. Construcc 62 [306], 213-229. http://dx.doi.org10.3989/ mc.2012.60710.

18. Barreca, F.; Fichera, C.R. (2013) Use of olive stone as an additive in cement lime mortar to improve thermal insulation. Energy and Buildings 62, 507-513. http://dx.doi.org/10.1016/j. enbuild.2013.03.040.

19. La Rubia-García, M.D.; Yebra-Rodríguez, A.; ElicheQuesada, D.; Corpas-Iglesias, F.A.; López-Galindo, A. (2012) Assessment of olive mill solid residue (pomace) as an additive in lightweightbrick production. Construct. Build. Mat. 36, 495-500. http://dx.doi.org/10.1016/j.conbuildmat. 2012.06.009

20. De la Casa J.A.; Romero, I.; Jiménez, J.; Castro, E. (2012) Fired clay masonry units production incorporating two-phase olive mill waste (alperujo). Ceram. Int 38 [6], 5027-5037. http://dx.doi.org/10.1016/j.ceramint.2012. 03.003 .

21. Mekki, H.; Anderson, M.; Benzina, M.; Ammar, E. (2008) Valorization of olive mill waste water by its incorporation in building bricks. J. Hazard. Mat. 158, 308-315. http:// dx.doi.org/10.1016/j.jhazmat.2008.01.104.

22. Mekki, H.; Anderson, M.; Amar, E.; Skyrratt, G.; Benzina, M. (2006) Olive oil mill waste water as a replacement for fresh water in the manufacture of fired clay bricks. Journal of Chemical Technology \& Biotechnology 08 [81], 1419-1425. http://dx.doi.org/10.1002/jctb.1579.

23. Eliche-Quesada, D.; Iglesia-Godino, F.J.; Pérez-Villarejo, L.; Corpas-Iglesias, F.A. (2014) Replacement of the mainly fresh water by wastewater olive oil extraction in the extrusion of ceramics bricks, Construct. Build. Mat. 10 [68], 659-666. http://dx.doi.org/10.1016/j.conbuildmat.2014.07.017.

24. De la Casa, J.A.; Castro, E. (2014) Recycling of washed olive pomace ash for fired clay brick manufacturing Construct. Build. Mat. 61, 320-326 http://dx.doi.org/10.1016/j. conbuildmat.2014.03.026

25. Zhang, L. (2013) Production of bricks from waste materials - A review. Construct. Build. Mat. 47, 643-655. http://dx.doi.org/10.1016/j.conbuildmat.2013.05.043

26. Neves Monteiro, S.; Fontes Vieira, C.M. (2014) On the production of fired clay bricks from waste materials: A critical update. Construct. Build. Mat. 68, 599-610. http://dx.doi. org/10.1016/j.conbuildmat.2014.07.006.

27. Santos, S.F.; Tonoli, G.H.D.; Mejia, J.E.B.; Fiorelli, J.; Savastano Jr, H. (2015) Non-conventional cement-based composites reinforced with vegetable fibers: A review of strategies to improve durability. Mater. Construcc. 65 [317]. http://dx.doi.org/10.3989/mc.2015.05514.

28. NA 1957. Algerian Norms (1995) Firing Clay bricks Determination of water absorption coefficient.

29. NF P 94-051. French Norms (1994) Determination of the Atterberg limits. Liquid limit-plastic limit.

30. Weng, C.H.; Lin, D.F.; Chiang, P.C. (2003) Utilization of Sludge as Brick Materials. Advances in Environmental Research. 7, 679-685. http://dx.doi.org/10.1016/S1093-0191 (02)00037-0.

31. Citroni. J.; Rodriguez. M.; Carrasco, M.; Avendaño. M.; Sota. JD.; Franzoy. MI.; Baldó. E. (2006) Desarrollo de ladrillo cerámico alivianado a partir de la utilización de residuos. Recicladode residuos de construccion y demolicion (RCD) y de residuos de procesos (RP), 
PROCQMA-Universidad Technológica National, 11 y 12 de Abril, San Rafael, Mendoza, Argentina.

32. NA 5023. Algerian Norms (1995) Firing Clay bricksDetermination of compressive strength of bricks.

33. Eliche-Quesada, D.; Martínez-García, C.; Martínez-Cartas, M.L.; Cotes-Palomino, M.T.; Perez-Villarejo, L.; Cruz-Perez, N.; Corpas-Iglesias, F.A. (2011) The use of different forms of waste in the manufacture of ceramic bricks. Applied. Clay. Science. 52, 270-276. http://dx.doi.org/10.1016/j.clay. 2011.03.003.

34. Karaman, S.; Ersahin, S.; Gunal, H. (2006) Firing temperature and firing time influence on mechanical and physical properties of clay bricks. J. Scientific and Industrial Research. $65,153-159$. 